\title{
CONNECTION BETWEEN CIVIL SERVICE AND PERSONAL DEVELOPMENT
}

\author{
A KÖZSZOLGÁLAT ÉS A SZEMÉLYISÉGFEJLESZTÉS
}

KAPCSOLATA

\author{
Zsuzsa DARIDA ${ }^{\mathrm{a}}$ \\ a Széchenyi István Egyetem Regionális- és Gazdaságtudományi Doktori Iskola, Address: Pipacs u. 18/A. \\ Herend H-8440, phone: +36-20-261-4615, e-mail: darida@citromail.hu
}

Cite this article: Darida, Z. (2015). Connection Between Civil Service and Personal Development Analysing the Demography and Migration Related Challenges within the Internal Periphery of SouthHeves. Deturope, 7, 2: 220-232

\begin{abstract}
The public administration of the modern age and the significant changes taking place in the public administration in these days gave rise to the lecture. After a brief review of the historical antecedents a multi-stage process of reforms is mentioned as a result of which the so called closed system of public administration of Hungary became loose in a sense and the stiff margins which hindered the realization of the human resource management functions and presented a parting line between the establishments of the civil service and the competitive sector have been altered in a certain way. The present study deals with the direction towards which the present system proceeds and also with some management functions (e.g. performance evaluation) the importance of which is stressed greatly in the past few years. Finally a new field of research is dealt with which examines the efficiency of the personal development trainings as a special segment of these changes.
\end{abstract}

Keywords: civil service system, human resource, personal development training, public administration, self-awareness, Social-therapeutic roll play

\section{Kivonat}

A modern kori közigazgatás, és a közigazgatásban napjainkban is zajló jelentős méretű változások teremtik meg azt az alapot, melyre az előadás felépül. A történelmi előzmények vázlatos ismertetése után az a több lépcsős reformfolyamat kerül említésre, mely odáig vezetett, hogy a Magyarországon alkalmazott un. zárt közigazgatási rendszer bizonyos értelemben fellazuljon, és azok a merev határok, melyek az emberi erőforrás menedzsment funkciók megvalósításában választóvonalat húztak a közszolgálat és a versenyszféra intézményei közé, bizonyos módon átalakuljanak. Jelen tanulmányban szó lesz arról az irányvonalról, mely felé a jelenlegi rendszer elmozdult, valamint érintőlegesen egyes menedzsment funkciókról (pl. teljesítményértékelés), melynek használatára az elmúlt években egyre nagyobb hangsúly helyeződik. Végül szóba kerül egy új kutatási terület, mely e változások egy speciális szeletének, a képzéseknek, azon belül a személyiséget fejlesztő tréningeknek a hatását/eredményességét igyekszik vizsgálni a jövőben.

Kulcsszavak: emberi erőforrás, közigazgatás, közszolgálat, személyiségfejlesztés, önismeret, Szociálterápiás Szerepjáték 


\section{INTRODUCTION}

\section{The concept of the civil service}

Who can be considered as civil servants and how can the system they belong to be defined? These are unavoidable questions.

There are various answers depending on the different historical ages and different places. The present article uses the definition of György Gajduschek (Gajduschek, 2008, p. 8) as a starting point. According to this civil service contains three fields:

- $\quad$ people working in the public sector (civil servants);

- the specific way of people's employment, that is, the system of employees (human resource management); and

- the system ensuring the public services.

In the following the conceptual sphere of the first two fields is dealt with. To make these concepts more exact the effective legal regulation of Hungary is used. Accordingly, civil servant is a person who falls within the law of CXCIX 2011. (Kttv.) and public service is a system which is referred to by this law.

Next, the history of development of the public administration is taken into consideration. It will be examined how today's public service systems obtained their present form.

\section{Brief history of public administration}

When did public administration start? According to the scientific literature listed in the bibliography very simple directing, governing functions can already be detected at ancient communities/societies.

The first significant administrative actions could already be experienced in the ancient empires (China, Egypt, Roman Empire). In spite of the remarkable organization of these empires, the modern public administration has its roots in the organizational, administrative functions of the Roman Catholic Church. The example of the church influenced the secular life too. The use of written records, territoriality and hierarchical structure were present at the royal courts where the public (state) sector and the private (royal) sector were not separated from each other.

The germs of the public administration as it is interpreted today appeared in Europe in the time of the absolute monarchies. The state became centralized: government offices or ministries and regular army were established, central taxation was introduced. The system of 
central power was organized and the foundation stone of the modern public administration was laid. (Lőrincz, 1999)

From the beginning of the 19th century it became generally accepted that serving of the public interest is the task of the ruler or the state. Differentiation between the public (state) sector and the private (royal) sector started. Functions were assigned to officials by the ruler so that they took part in preparing decisions and shaping general politics.

At this time the public administration was a closed system, it firmly followed the methods used in the army. However, till the end of the century this similarity faded and a system of public administration came into being in which the selection of manpower was an objective process during which the required skills/qualifications are taken into consideration and advancement was bound to rules. The system was calculable and stable. Advantages (e.g. higher salary, favourable employment regulations, right to pension) were offered to people working in the public sector which made this sort of career attractive. (Gajduschek, 2008, pp. 35-37 and Csizmadia, 1976, p. 448)

If the horizon of our research is widened or its focus is moved from Europe to America, it can be seen that the course of development in the United States of America and the Englishspeaking world is different from the traditional European model. In Europe a rather closed bureaucratic system controlled by the state was established, while in America an open, so called spoils system ${ }^{68}$ came into being which originally was built from below and based on customary rights (Balázs, 2014 p. 5). However, by the middle of the 20th century it changed significantly. Nowadays a closed system is used in the United States of America, too.

But let us turn back to Europe. The development of public administration was naturally affected by World Wars I and II. In Europe the function of public administration became more and more important after the Second World War. Moreover, international and overnation bureaucracy also showed up. (Lőrincz, 1999)

In the 1970s and 1980s a new tendency appeared which followed the directives of the neoclassic economics. Its basic idea is shown in the following table:

\footnotetext{
${ }^{68}$ It was called spolis system because the civil servants were selected for serving the given political system and they could take advantage of it till that particular political party ruled. This system had anomalies. When it was realized, the National Civil Service Reform League was established in 1881 and development of the system of the civil service based on careers started. Naturally, the changes in the legal regulation took place decades after that.
} 
Darida, Z.

Table 1

\begin{tabular}{|l|l|}
\hline Private & State \\
\hline Effective & Wasteful \\
\hline Produces & Spends \\
\hline Takes care of his consumers & $\begin{array}{l}\text { Users of the public services are at the mercy of } \\
\text { the state }\end{array}$ \\
\hline
\end{tabular}

Source: Gajduschek, 2008 - edited by the author

Simply it can be said that whatever is "private" is good, whatever is "state" is bad.

The New Public Management (NPM) ${ }^{69}$ is based on this policy (Bordás, 2014, p. 4) which considers the "market" as the ideal model. A requirement of this policy is that the closed, rigid, centrally controlled system should be replaced by a system of the competitive sector which system is more flexible and its renewal is permanently forced. (Gajduschek, 2008, pp. 42-52)

\section{Public administration in Hungary in our days}

In Hungary after the Second World War, during the socialism a development different from the European tendency could be experienced. The communist party basically used the open spoils system.

The civil servants served the actual political system. A typical ideology of the system was that people working as civil servants are not different from the other working people of the society. Peasants and labourers could work as civil servants. A consequence of this system was that the officials were ill-qualified and corrupt. Consolidation started in the middle of the 1970s. In 1978 the College of Public Administration was founded and necessity of introducing the closed system has been revealed in the scientific literature since 1980 . (Gajduschek, 2008, pp.42-52)

After the so-called political transformation in 1989 a multi- stage reform process started in Hungary. The aim of the transformation of the public administration was to reorganize the public sector according to a civil conception. (Balázs, 2011) A significant stage in this changing process - after the political transformation - was the birth of the Act XXIII of 1992 on the Legal Status of Civil Servants (Ktv.) which laid down the basis of a new, democratic system of public administration $^{70}$. (Gajduschek, 2007)

\footnotetext{
${ }^{69}$ New Public Management: the methods of organization, management and administration used successfully in the private sector are enforced for use in the practice of the public management. (Balázs, 2011)

${ }^{70}$ At the time of the political transformation the two large subsystems of the public administration: the state management and the local government were differently weighted. After a wide-ranging professional preparation
} 
This Act and its subsequent modifications show efforts to make the career of the civil servants attractive and vocational and to clearly separate from legal relations of other employees.

Different from the practice used in the times before the political transformation the new system was a strongly controlled, bureaucratic, so called closed system. The legal regulation controls the legal relations circumstantially in every aspect starting from the recruitment ${ }^{71}$. (Gajduschek, 2008, pp. 42-52)

This closed system was continuously affected by the previously mentioned New Public Management campaign which gained a larger and larger ground in our country too ${ }^{72}$. A slow transformation started in the focus of which the reform concerning the staff of the public administration has been taken since 2006 .

After the change of government in 2010 new intensive changes occurred on the basis of the Magyary Program for Public Service. The Magyary Programme is not merely a plan but it is a program which "determines the objectives, the fields of intervention and the forthcoming measures." (Magyary program, 2011)

The new rules which were put into force during realization of the program resulted in further intensive changes in the organization and the staff of the public administration 73.

In which direction the Hungarian public administration proceeds is difficult to predict since these changing processes has not been finished yet (some of them are still in progress). Objective evaluation cannot yet be done as the subject matter is very close in time. (cp.:Hazafi, 2014) The main direction of planning is a centrally regulated public administration which also uses the manager tools of the competitive sector. Seniority and at the same time the personal attitude, talent as well as skills must be considered, and it is important for the civil servants to improve their professional knowledge continuously. (Poór, Karoliny, 2014)

An example to this is the introduction of the new system of the efficiency evaluation (2013) which on the one hand builds upon the sphere of activity and the tasks of the civil

the government decision 1100/1996 (X.2) was accepted the aim of which was a middle-distance complex reform process to be carried out. (Balázs, 2011)

${ }^{71}$ The system of competition, the admission, making the contract (the assignment), the promotion, the payment (salary) the system of compulsory trainings (basic and higher level examinations as well as examination in administration) were determined. An early type of efficiency measurement, the assessment also appears.

72 The requirements which were raised during the integration process in Europe and during joining to the Union were determinant in the conception of developing the New Public Management in Hungary. (Balázs, 2011)

${ }^{73}$ In the past four years the uniform integrated system of customer service, the government administrators' windows, the district offices have been established, the integration of the government offices has come into being, regulations for the career of the civil servants and some new rules for proceedings have appeared. 
servants on the other hand upon the personal ability, skills and competence of the person performing the task. The aim of the efficiency evaluation (in addition to performance enhancement resulting from financial advantages/disadvantages bound to the measurement) is to map the weakness of the civil servants performing the task and to train them in the field they most need help in ${ }^{74}$.

This system is based on the fact - which in the competitive sector has been known for a long time - that an organization can be successful indeed if it can use the manpower effectively ${ }^{75}$.

At this point we must stop for a moment. Human resource has several special properties. One of these properties is that it is able to be renewed but it might as well get entirely unserviceable, burnt out. It is like the battery of an automobile which during operation - under suitable conditions - is able to be charged up, but if it used unsuitably it may run down and recharging of it needs the use of great energy.

That is why "it is very important to bring the people performing their work (both the leaders and the personnel) into the focus of the operating processes and ensure attractive working conditions for them and keep them in the system for a long time as they represent the most important resource of the public service, they create new value and they are able to develop permanently and capable of introducing new ideas.”(Bokodi, Szakács, 2014)

\section{A new field of research, trainings including the effect of the personality development}

"It is not easy to decide in which direction is worth to start if development is required even if we know that other states in the European Union also search for solutions in order to realize a more effective public administration and a satisfactory career in this profession." (Krauss, Petro, 2014)

Nevertheless, I would like to mark out a possible direction of research - within the scope of the system of the public administration as it is required to be implemented - and present it to the readers who are interested in it.

\section{The starting point of the research}

The changes occurring in the civil service in the last one and a half decade as described earlier make people doubtful even if the aim is clear and logical. There is a continuous change in the

\footnotetext{
${ }^{74}$ See: Kttv. $130 . \S, 133 \S$ and $154 \S$ as well as Government decision 10/2013. (I.21.) about the efficiency evaluation of employees in the public management.

${ }^{75}$ Management of the human resource within public services on the one hand must be adjusted to steady changes, shifts in direction and stress. On the other hand it must meet the challenges proactively. (Bokodi, Szakács, 2014)
} 
system and in the task to be performed. In the last few years stability and calculability of the civil service have become insecure. Stress is often experienced within the system and fluctuation is more and more common. Besides this, events happening independent of the system of the public management also make their influence felt.

Changes in the society, the aftermath of the economic crisis in 2008 generated difficult conditions in the personal life of number of people. Many of them had to or still have to face existential problems which affect their performance. There is no doubt that oppressive troubles may distract attention from work, increase the number of mistakes resulting in reduced performance however "the attitude, the working behaviour, the loyalty, the commitment and professionality of the person performing the job and also the quantity and quality of his daily performance is of no minor importance.” (Bokodi, Szakács, 2014 p. 136)

Based on the above we can state that the efficiency of the people working in public administration is influenced by several factors and it is important how these people react to these life situations and naturally, the reaction of the system or the official machinery is also important ${ }^{76}$ because the long-term success of the given organizations - in the domain of both the cometitive field and the public sector - depends more and more on "the attitude, commitment and willingness of the staff members." The man became the central, determinant figure of the world of work. (Szakács, 2014, p.88)

\section{The man as a special resource}

Civil servants just like other people are resources who take not only their working ability but their individual history of life along with them to their workplace. Their attitude to work, their suitability and volition is influenced by their life history and these factors determine their efficiency to a great extent. (Huber, Schild, 2007) Realizing this fact, trainings for developing competency and skills became more and more important besides the traditional trainings giving theoretical knowledge. (Linder, 2014, p. 40)

Our life story, attitude to performance, willingness to meet the requirements, ability to develop and many more of our skills necessary for work take root in our babyhood ${ }^{77}$, but they can be influenced by personal experiences. It often happens that unprocessed traumatic memories keep us back from being objective or prevent us from acting properly. Sometimes we face problems which seem unsolvable. What is more, the time we spend with work uses

\footnotetext{
${ }^{76}$ Solutions and methods which are profitable for the public management and the civil servants must be admitted and must be made segments of the system. (Bokodi, Szakács, 2014)

${ }^{77}$ The scientific literature emphasises the importance of the family as primary group of socialization in shaping the careers of individuals. (Huber, Schild, 2007, p. 62)
} 
up a significant amount of our energy which may reduce our motivation and enthusiasm. (Marok, Martos, 2006)

The employees who handle people (e.g. receive clients) are subjected to increased burden. They have to cope with such a large quantity of problems of different quality which would put even the most competent person to the test.

In my opinion developing self-awareness through which another type of problem handling and proper way of acting can be learnt is very important. In this field support should be given to employees in order to "help them form their own system of acting, to make them realize, consider and possibly change their method." ${ }^{, 78}$ (Huber, Schild, 2007, p. 67)

As a result of the development in the last decades knowledge management including competence management ${ }^{79}$ have become fashionable methods in the world of the different economical organizations. "Today appreciation of knowledge... taking different connecting fields into focus is perhaps natural to everyone" (Bencsik, Marosi, Döry, 2012) in the competitive sector. But how do organizations which are not profit oriented approach this question? Is maintenance of people as "means of production" important for them? If yes, what can they do to realize this aim?

\section{Protection and regeneration of human resource}

One of the basic pillars of the reform process which started in the 1990s is that public administration should be made stable and conditions for high level quality service should be established. However, the well-defined regulations and the reliably operating system in itself do not guarantee efficiency and quality. (Balázs, 2011) Selecting, developing and training of the members of the staff are important tasks in professional point of view. (Verebélyi, 1998, Kttv., 273/2012 (IX.28) Korm.r.)

These two functions of the human management (selection and training/development) are connected to each other in a certain manner and both are important in view of the result (i.e. public management providing a quality service). In respect of the present theme the importance of trainings especially the ones which aim to develop self-awareness and personality based on team work is stressed.

According to the representatives of the humanistic psychologists (including Abraham Maslow, Carl Rogers, Routh Cohn) personal development is a natural ambition of the

\footnotetext{
${ }^{78}$ In the Hungarian translation the word method is used, however, its meaning in the context is rather "their actions, treatment and attitude to others".

${ }^{79}$ Competence management is a "complex means in the process of the human resource management which is used for ensuring performance at a required level by developing the competence of the employees". (Linder, 2014 p. 41)
} 
individuals. (Huber, Schild, 1996) People's success in life can be promoted by catalysing the starting process of development thereby helping to form their positive self-image. A tool to this catalysing process is to keep trainings to develop self-awareness/personality. ${ }^{80}$

When personality development trainings are held in small groups the members of the group can share their problems with each other according to predetermined rules. On the basis of the reflections of the members of the group it will be clear for them that others also had similar experiences, they are not the only ones who have difficulties. From these shared experiences they can get ideas how to solve those problems in the future which they were not able to solve or only could solve partially earlier. People taking part in the group work can try out new alternative behaviour in a safe environment and can get immediate feedback which helps them choose and practise the most proper behaviour. Finding the proper behaviour will help them perform their task in a higher level. (HR Portál, 2014)

The group method makes it possible for the participants to enlarge their problem solving repertory, and they will be able to make use of the experiences gained during the training not only in their work but in their private life too. (cp.: Eisenbarth, 2004)

\section{OBJECTIVES AND METHODS}

\section{A possible new field of research}

This is the field I would like to examine more closely during my research in the forthcoming times, namely the outcomes of the self-awareness trainings and their effect on the employees and the organization. According to my presumptions - as I have written about it before - it is imperative to know what kind of self-knowledge the workforce has, what kind of behaviour techniques and acting schemes he or she has acquired in life and how they apply these techniques during their work. I am to prove the fact that the higher the level of self-knowledge they have, the more effectively they can apply their adaptability skills in new situations. With better stress-resistability and improved problem-solving skills they will carry out their task more fruitfully.

Though it is true that civil servants do not contribute to the industrial output directly, but they give the operational background, so they have an important role. As I noted before, due to the changes both in the economy and the political and social arena, it is harder and harder to find a committed empolyee who is fit for working in the public sector. Also it is more and

\footnotetext{
80 "The starting point for organizing groups of self-awareness is the effort made in order to help people live a better, more valuable, more satisfactory life". (Huber, Schild 2007 p. 97)
} 
more difficult to keep the ones who have already been working in the field. The recruit, the selection and the training of new workforce is very costly and time-consuming task for the organizations. In my opinion - and I am about to prove it to the best of my knowledge - as a result of personality-developing sessions:

- the situation awareness and problem solving skills of the public servants improve

- they acquire better solving skills for situations that seem to be humanly problematic ${ }^{81}$

- a net formed among the public servants aids them to be more loyal and more motivated

- ultimately their satisfaction at the workplace strengthens

- the rate of changing workplace decreases

The decreasing fluctuation brings economic benefits to the administrative organ (more precisely it yields decreasing costs as for the selection, the hiring and the training of the new workforce). This present research is a stepping stone in a process of which the ultimate goal is to examine whether the personality-development session for the public servants is an economically remunerative investment ${ }^{82}$.

It is important to state that the value of the training sessions held in the administrative field has been increased. The system of further training for public servants and the methodology of these trainings have been fundamentally changed. We can witness a shift in paradigm in which training and learning methods customized for the public servants are applied. We have some experience in the efficiency of the new system but this special domain of the training system (the effect of the personality-developing trainings) to my knowledge has not been examined yet.

The research is conducted according to the following logic. Advantageously, a long-term (twelve-month long) examination is proposed and directed to two groups (one attending the self-awareness trainings and a so called control group not receiving trainings). There will be three samplings, one before the training, one immediately after the training and one at the end of the follow-up period. The participants are selected from voluntary people so that each unit of the examined organization is represented. The group method to be used during self-

\footnotetext{
${ }^{81}$ For example the administrators deal with customers more patiently, tolerably. They handle internal stress (that distract their attention from the work done effectively) better, and settle their conflicts in a reassuring way etc.

${ }^{82}$ I find the demonstration of the above mentioned statements important because the tax paid by the citizens can be spent rightfully on personality-trainings by the govermnemt only if they are proved to bring positive results for example: they bring justifiable economic benefits or fall of costs.
} 
awareness trainings is the so called Social-therapeutic roll play (evolved in Germany in the 1970s as Sozialtherapeutischen Rollenspiel) which has been used in Hungary for about twenty years. (Stein, 2009)

\section{CONCLUSION}

The study introduces the use of human resource management and its relevance to the public administration. The personality development can be an important tool for more efficient work, it is more adequate to deal with problems in this field.

The study has a brief introduction to the historical development of public administration with the Hungarian elements and also notes why it is important for the personal development in public administration. The study actually is an idea of research that I tried to justify. I submitted the appropriate methods and tools of the investigation that are still looked for.

During my investigation I would like to find the answer to the following questions: Exactly in which areas and how can the change caused by development be experienced? Can the effects of it be experienced directly or only indirectly? My aim is to make the effects of the personal development trainings measurable and examine how the changes can be experienced (or can they be experienced at all) during one's job. I will examine how the connections of people within the target group and the control group change and also how the connections between the members of the two groups change. I will collect information about the motivation, loyalty and contentment of the civil servants and about the changes which may come about. At present I am looking for the suitable methods and tools to be used during my investigation.

The research focuses on a delicate field which is very difficult to measure. It is not by chance that the literature dealing with this theme especially with the results of the practical experiences is restricted. Relatively few attempts have been made to measure the unmeasurable. Still, I will make the attempt.

I hope I will succeed.

\section{REFERENCES}

Bokodi, M., Szakács, G. (2014): Characteristics of Civil service organisations and HR management. In: Bokodi, M-, Hazafi, Z., Kun, A., Petrovics, Z., Szakács, G.,: Civil service career and HR management. 135-175. o. Retrieved November 20, 2014. from http://magyaryprogram.kormany.hu/download/b/fa/a0000/_Tanulmanykotet_online_EN AROP2217.pdf 
Balázs, I. (2011): A közigazgatás változásai Magyarországon és Európában. [Changes in Public Administration in Hungary and Europe] Retrieved Oktober 15, 2014, from http://jog.unideb.hu/documents/tanszekek/kozigazgatasi/segedanyagkosaras.pdf

Balázs, I. (2014): Humánerőforrás és a közszolgálati menedzsment sajátos müködése. [Specific operation of the human resources and public service management] Nemzeti Közszolgálati Egyetem, Budapest

Bencsik, A., Marosi, I., Dőry, T. (2012): Vágyott kultúra és reális értékítélet. Tudásmenedzsment-rendszer kiépítésének elöfeltétele egy felsőoktatási intézményben. [The desired culture and realistic judgment - Prerequisites for building a knowledge management system in an institution of higher education] Retrieved Oktober 10, 2014, from

http://search.ebscohost.com/login.aspx?direct=true\&db=a9h\&AN=75173049\&lang=hu $\&$ site $=$ ehost-live

Bordás, M. (2014): A közigazgatás-tudomány mint új tudományág. [The administration science as a new discipline] Stádium Társadalmi és Kulturális Hírlap 3., 1., pp. 4-5.

Csizmadia, A. (1976): A magyar közigazgatás fejlödése a XVIII. századtól a tanácsrendszer létrejöttéig. [The development of the Hungarian administration from the eighteenth century until the establishment of the council system] Akadémiai Kiadó, Budapest

Eisenbarth, K. (2004): Az SzTSzJ, mint a személyiség utánérésének (utóérlelödésének) szelid módszere. [STR - A gentle method for post-maturing of the personality] Konferencia előadás. Elhangzott a IV. Magyar Szociálterápiás Napok, Budapest, 2004. június 18.

Gajduschek, Gy. (2008): Közszolgálat. [Civil service] KSZK ROP 3.1.1. Programigazgatóság, Budapest

Gajduschek, Gy. (2007): Politicisation, professionalisation, or both? Hungary's civil service system. In: Communist and Post-Communist Studies, 40., pp. 343-362

Hazafi, Z. (2014): The new civil service career - legal and human resource dimensions of civil service developments. In: Bokodi, M., Hazafi, Z., Kun, A., Petrovics, Z., Szakács, G.: Civil service career and HR management. 11-89. o. Rertieved November 13, 2014, from

http://magyaryprogram.kormany.hu/download/b/fa/a0000/_Tanulmanykotet_online_EN AROP2217.pdf

http://www.hrportal.hu/index.phtml?page=szemelyzetfejlesztes_elmelet Retrived: November 7, 2014.

Huber, H.; Schild, W. (Hrsg.) (1996): Praxis des Sozialtherapeutischen Rollenspiels. Sozialarbeit - Selbsterfahrung - Supervision. [Practice of Social Threapy Roleplay. Social work - Self-knowledge - Supervision] Don Bosco Verlag, München

Huber, H., Schild, W. (2007): A vágyak tava. A szociálterápiás szerepjáték gyakorlata. [The lake of desires - Practice of Social Threapy Roleplay ] Magyarországi Szociálterápiás Szerepjáték Egyesület, Budapest

Krauss, G., Petro Cs. (2014): Az illetményrendszer aktuális kérdései. [Current issues in the salary system] In: Pro Publico Bono Magyar Közigazgatás, 2., pp. 56-68.

Magyary Zoltán Közigazgatás-fejlesztési Program (MP 11.0) [Zoltán Magyary Public Administration Development Program] Közigazgatási és Igazságügyi Minisztérium, 2011. június 10, Budapest

Marok, Zs., Martos T.(2006): Pedagógushivatás-személyiségfejlesztés. [Teacher's profession, personality development] In: Iskolakultúra 16., 2., pp. 114-122.

Linder, K. (2014): Nemzetközi trendek a közszolgálatban. [International trends in the civil service] Nemzeti Közszolgálati Egyetem, Budapest

Lőrincz Lajos: Közigazgatás: Tegnap, ma, holnap. [Civil service: Yesterday, today, tomorrow] In: Tér és Társadalom, 13., 3., p. 5. 
Poór J., Karoliny M.: A közszféra hatékonyságát befolyásoló HR menedzsment technikák és módszerek [HR management techniques and methods influencing the efficiency of the public sector] Retrieved November 13, 2014, from http://www.nyme.hu/fileadmin/dokumentumok/atfk/tematikak/HUMAN/MA_any/EEfogl_szerv_felep_1.pdf

Stein, A. (2009): Sozialtherapeutisches Rollenspiel. Eine Methode in der psychosozialen Arbeit. [Social Therapy Roleplay. A method of psycho-social work] Ernst Reinhardt Verlag, München Basel

Szakács G. (2014): Az emberi erőforrás gazdálkodás fejlesztésének elméleti kérdései a magyar közszolgálatban. [Theoretical issues of the development of human resource management in the Hungarian civil service] Nemzeti Közszolgálati Egyetem, Budapest

Verebélyi I. (1998): Összefoglaló a közigazgatási reformfolyamat első szakaszáról és a további tennivalókról. [Summary of the first stage of the administrative reform process and the further tasks] In: Magyar Közigazgatás, 48., 6., pp. 321-336.

Verebélyi I. (1998): Összefoglaló a Közigazgatási reformfolyamat első szakaszáról és a soron következő feladatokról II. [Summary of the first stage of the administrative reform process and the next tasks II.] In: Magyar Közigazgatás, 48. évf. 6. szám 414-421. o.

\section{Documents}

1100/1996 (X.2.) Government Decision

10/2013. (I. 21.) Government Regulation about the efficiency evaluation of employees in the public management

2011. évi CXCIX. (Kttv.) Civil Servants Act

273/2012. (IX. 28.) Government Regulation about the furder training of civil servants

1992. évi XXIII. (Ktv.) Act on the Legal Status of Civil Servants 